Arab World English Journal (AWEJ) Special Issue on Covid 19 Challenges April 2021

DOI: https://dx.doi.org/10.24093/awej/covid.8

Pp. 107126

\title{
Engaging Students Online with Technology-Mediated Task-Based Language Teaching
}

\author{
Surya Subrahmanyam Vellanki \\ English Language Center \\ University of Technology and Applied Sciences \\ Nizwa, Sultanate of Oman \\ Corresponding Author: drvssurya@gmail.com
}

\section{Sasidhar Bandu}

Department of English, Deanship of PYP

Prince Sattam Bin Abdulaziz University

Al-Kharj, Saudi Arabia

Recived: $3 / 3 / 2021$

Accepted: 4/7/2021

Published: 4/26/2021

\begin{abstract}
The Covid-19 pandemic effected a sudden shift to online teaching, prompting teachers to implement many uncommon or even unusual teaching techniques in this unforeseen context. This precipitous move to online teaching has radically altered our teaching practices, where teachers have had to either completely do away with traditional practices or modify them in significant ways. One of the primary concerns of online teaching voiced by many teachers is to hold students' interest and keep them engaged in the virtual classroom. Another challenge has been to make students interact with each other and the teacher. The authors of this paper believe that Task-Based Language Teaching (TBLT) addresses these concerns head-on. There are two reasons for this: first, its emphasis on real-life language through meaningful tasks; and second, it is student-centered. This paper provides a brief background of TBLT and technologymediated TBLT. It will show how some coursebook materials could be used in TBLT to help online learners improve their language skills. The paper also outlines with examples how technology-mediated tasks could be deployed to encourage learners to use language in productive ways. Finally, the authors discuss some of the anticipated challenges concerning the application of TBLT in online teaching and learning contexts.
\end{abstract}

Keywords: collaborative tasks, online interaction, online teaching, student-centered teaching, Task-Based Language Teaching, technology-facilitated tasks

Cite as: Vellanki, S. S., \& Bandu, S. (2021). Engaging Students Online with Technology-Mediated Task-Based Language Teaching. Arab World English Journal (AWEJ) Special Issue on Covid 19 Challenges (1) 107 126. DOI: https://dx.doi.org/10.24093/awej/covid.8 
Arab World English Journal (AWEJ) Special Issue on Covid 19 Challenges April 2021

\section{Introduction}

The Covid-19 pandemic effected a sudden shift to online teaching, prompting teachers to implement many uncommon or even unusual teaching techniques in this unforeseen context. This precipitous move to online teaching has radically altered teaching practices, where teachers have had to either completely do away with traditional practices or adapt them in significant ways. The new-age digital technologies are attempting to address every educational need in the current scenario. Innovative applications and hi-tech platforms have enabled teachers to enhance the language learning ability of their students. Further, the forced remote teaching necessitated by Covid-19 has compelled educators, institutions, and organizations to quickly upgrade teaching technologies and create awareness of how these could be adapted and integrated into their particular contexts.

Among the different methods that have been used for online language learning, TaskBased Language Teaching (TBLT) has yielded promising results. Though TBLT is not a new method in language teaching, research on its application in virtual contexts has been limited. Let us first look at what TBLT is, and then discuss how it can be integrated with technology in online learning.

\section{Literature Review}

\section{Definition of Task-Based Language Teaching}

Task-based Language Teaching, as the name suggests, relies entirely on communicative tasks, and has its roots in the Communicative Language Teaching method and Second Language Acquisition (SLA) studies (Samuda \& Bygate, 2008). TBLT came as a viable option to transcend the limitations of methods that focused on form. One of the limitations noticed by educators was the students' inability to communicate adequately in English despite having learnt the accurate use of grammatical forms taught in the Presentation, Practice, Production (PPP) approach. Prabhu's (1987) success in his Communicational Teaching Project in primary and secondary schools of Bangalore prompted many researchers and academicians to use TBLT, since the focus of this method is almost entirely on meaning rather than on grammatical structures. TBLT does not look at language learning as processing internally with grammar systems, expressions and vocabulary. Instead, TBLT proponents believe that learners would be able to acquire language easily if they work through meaningful tasks that prompt them to use the target language in natural contexts (Long, 1985; Samuda \& Bygate, 2008). The tasks and outcomes should have some kind of practical significance and application. Rod Ellis, an exponent of TBLT, also emphasizes that TBLT can make use of learners' natural abilities and help leaners acquire language incidentally when they engage with language as a meaning-making tool in tasks.

\section{A Task in Task-Based Language Teaching}

A 'task' has been defined differently by different researchers. A task, according to the Longman Dictionary of Applied Linguistics (2010), is "an activity which is designed to help achieve a particular learning goal" (p. 584). Task is defined as "a piece of work undertaken for oneself or for others, freely or for some reward" by Long (1985, p. 89). In other words, a task is many different things that people do in their daily lives and that there should be an apparent significance to 'real-world' activities. Prabhu (1987) defines task as "an activity which required learners to arrive at an outcome from given information", while a task, according to Breen (1987), is a "structured language learning endeavour" (p. 23) and refers to a variety of 


\section{Arab World English Journal (AWEJ) Special Issue on Covid 19 Challenges April 2021}

workplans, from simple exercises to complex lengthy activities such as problem-solving. He also argues that tasks provide the best means for teachers and students to jointly negotiate the content of a course (Breen, 1989).

Willis (1996) described task as a "goal-oriented activity" (p. 53) where the target language is used by the learner to accomplish a communicative purpose. Task, according to Skehan (1996), is an activity that has meaning as its principal focus; tasks should relate to real-world activities and the assessment of a task depends on its outcome. Lee (2000) defines task as a classroom activity in which learners achieve the outcome only by interacting mutually using language and by focusing on the exchange of meaning. For Ellis (2003), task consists of "a workplan that requires learners to process language pragmatically in order to achieve an outcome" (p.16). A task, as defined by Nunan (2004), is:

a piece of classroom work that involves learners in comprehending, producing or interacting in the target language while their attention is focused on mobilizing their grammatical knowledge in order to express meaning, and in which the intention is to convey meaning rather than to manipulate form (p. 4).

He also differentiates between real-world or target tasks and pedagogical tasks. While target tasks denote the real-world language use outside the classroom, pedagogical tasks imply the tasks that take place in the classroom. Van den Branden (2006) defines task as, "an activity in which a person engages in order to attain an objective, and which necessitates the use of language" (p. 4). According to Lai and Li (2011), "Tasks should be holistic activities in which learners make use of their language and (cross-) cultural and communicative resources to achieve some nonlinguistic outcome through stretching their linguistic, (cross-) cultural, internet-based communication, and digital literacy skills" (p. 501). Whatever the definition be, the underlying common features of tasks would be that they are meaning-oriented, communicative in nature, and consider both cognitive capacities and linguistic abilities of a learner.

\section{Types of Tasks}

There are a number of task types given by TBLT proponents. For the purpose of this paper, the authors will look at the kinds of tasks mentioned by Ellis (2003) and Willis (2007). Ellis (2003) identifies the following kinds of tasks based on their characteristics.

Table 1. Tasks and their Characteristics as Identified by Ellis (2003)

\begin{tabular}{|l|l|}
\hline \multicolumn{1}{|c|}{ Task } & \multicolumn{1}{c|}{ Characteristics of tasks } \\
\hline One-way vs. two-way & The way communication happens \\
\hline Open vs. closed & Many possible solutions vs. one possible solution \\
\hline Convergent vs. divergent & $\begin{array}{l}\text { A single outcome of the task vs. different possible outcomes } \\
\text { based on their opinions }\end{array}$ \\
\hline $\begin{array}{l}\text { Situational vs. interactional } \\
\text { authenticity }\end{array}$ & $\begin{array}{l}\text { Real-life/target tasks vs. tasks based only on interaction } \\
\text { without any situational authenticity }\end{array}$ \\
\hline $\begin{array}{l}\text { Input-based vs. output- } \\
\text { based }\end{array}$ & Tasks that involve receptive skills vs. productive skills \\
\hline Focused vs. unfocused & One intended for students to practice using a particular \\
\hline
\end{tabular}


Arab World English Journal (AWEJ) Special Issue on Covid 19 Challenges April 2021

grammatical structure vs. one intended to elicit general samples of language as learners communicate while doing a task

Willis and Willis (2007) categorize tasks into the following seven types:

- Listing - brainstorming/fact-finding. e.g., things, qualities, people, features, etc.

- Ordering and sorting - sequencing, ranking and classifying. e.g., sequencing story pictures, ranking according to cost, popularity, etc.

- Matching - listening and identifying, listening and doing, matching phrases/description to pictures, etc.

- Comparing - finding similarities and differences. e.g., comparing ways of greetings, 'spot the difference' activities, etc.

- Problem-solving - logic puzzles, real-life problems, etc. e.g., logic problems, giving advice, predicting a story ending, etc.

- Sharing personal experience - storytelling, anecdotes, opinions, reactions, etc. e.g., early schooldays, embarrassing moments, personality quizzes, etc.

- Projects and creative tasks - doing and reporting a survey, planning a TV show, etc.

\section{Task-based Learning Models}

Based on how tasks are used, various models of TBLT can be differentiated. The model suggested by Willis (1996) comprises pre-task, task-cycle and language focus. The modified model by Jane and Dave Willis (Willis \& Willis, 2007) consists of pre-tasks, tasks and posttasks. On the other hand, the models suggested by Long (2015), Norris (2009), and Van den Branden, Bygate, and Norris (2009) have pedagogic tasks sequenced in order of difficulty (as cited in González-Lloret, 2014). However, this model entails needs analysis, task selection and sequencing them into pedagogic tasks, materials and instruction development, teaching, assessment and program evaluation (Norris, 2009). It is important to note that Ellis (2003) is of the opinion that an approach based on 'themes' or 'topics' is more useful compared to a needsbased approach (as Long has suggested) for foreign language learners. Though many models have been recommended by various TBLT proponents, the models of Ellis (2003) and Willis and Willis (2007) have been considered for this research paper.

\section{TBLT Model Proposed by Rod Ellis (2003)}

Ellis presented a model that focuses on meaning and real-world activities that demand learners to process language for real situations. He also proposed a framework with task as its principal element sequenced pedagogically in three stages: pre-task, main task and post-task. The pretask phase has all the different activities that learners do to plan the performance of the task. In the during-task phase, different options related to task performance are planned by the teacher, who might want students to perform the task under a specified time, or allow them to look at the input data as they do the task, or introduce a surprise element in the task.

The third phase, post-task, contains activities such as 'consciousness-raising' activities to follow-up on task performance and to repeat the task. This phase also encourages learner reflection on their task performance. According to Ellis (2006), "only the 'during task' phase is 
Arab World English Journal (AWEJ) Special Issue on Covid 19 Challenges April 2021

obligatory in task-based teaching" (p. 20). However, other phases play an important role in making sure that the learners perform tasks to optimum effect.

Table 2. A framework for designing task-based lessons (Ellis, 2003)

\begin{tabular}{|c|c|}
\hline $\begin{array}{l}\text { Pre-task } \\
\text { (consciousness-raising activities) }\end{array}$ & $\begin{array}{l}\text { - Framing the activity } \\
\text { - (e.g., establishing the outcome of the task) } \\
\text { - Regulating planning time } \\
\text { - Doing a similar task }\end{array}$ \\
\hline During task & $\begin{array}{l}\text { - } \text { Time pressure } \\
\text { - } \text { Regulating topic }\end{array}$ \\
\hline $\begin{array}{l}\text { Post-task } \\
\text { (Focused communication activities) }\end{array}$ & $\begin{array}{l}\text { - Number of participants } \\
\text { - Learner report } \\
\text { - Repeat task } \\
\text { - } \text { reflection }\end{array}$ \\
\hline
\end{tabular}

\section{TBLT Model Proposed by Jane Willis (1996, 2007)}

Willis's $(1996,2007)$ TBLT model has three phases for instructors to design a task. First, there is a pre-task phase in which learners are introduced to the topic and the task. They are introduced to the target language and are provided the vocabulary and structures essential to complete the task. The teacher may also show a model of the task to the students. The next phase, the task cycle, comprises a task phase, a planning phase and a report phase. During the task phase, students discover the structures of language and vocabulary they should use based on the given model and learn from one another. Here, the teacher takes the role of a facilitator ensuring task progress and participation from all groups. In the planning phase, learners make plans on how to report to the other groups about the work given by the instructor. In the report phase, learners report on the task either orally or in written form and compare the results with other groups. In the last phase, which is the language focus or focus on form, learners' language is analyzed (e.g. through consciousness-raising activities), and they are made to notice the important aspects of language items. Finally, to improve their language accuracy, they are given oral or written language practice.

Table 3. Task-based lesson plan model (Willis, 1996, p. 38)

\begin{tabular}{|c|c|c|}
\hline \multicolumn{3}{|c|}{ Pre-task } \\
\hline \multicolumn{3}{|c|}{ Introduction to topic and tasks } \\
\hline \multicolumn{3}{|c|}{$\begin{array}{l}\text { Teacher explores the topic with the class, highlights useful words and phrases. } \\
\text { Learners may be exposed to examples. }\end{array}$} \\
\hline \multicolumn{3}{|c|}{ Task cycle } \\
\hline Task & Planning & Report \\
\hline $\begin{array}{l}\text { Students do the task in pairs } \\
\text { or small groups. Teacher } \\
\text { monitors; mistakes do not } \\
\text { matter. }\end{array}$ & $\begin{array}{l}\text { Students prepare to report. } \\
\text { Accuracy is important, so the } \\
\text { teacher stands by and gives } \\
\text { advice. }\end{array}$ & $\begin{array}{l}\text { Students exchange or } \\
\text { present report. Teacher } \\
\text { listens and then } \\
\text { comments. }\end{array}$ \\
\hline
\end{tabular}


Arab World English Journal (AWEJ) Special Issue on Covid 19 Challenges April 2021

Engaging Students Online with Technology-Mediated Task-Based

Vellanki \& Bandu

\begin{tabular}{|c|c|}
\hline \multicolumn{2}{|c|}{ Language focus } \\
\hline \multicolumn{2}{|c|}{} \\
\hline Analysis & Practice \\
\hline Students examine and then discuss. & Teacher conducts practice of new words \\
\hline
\end{tabular}

\section{Technology-Mediated Task-Based Language Teaching}

The new framework of TBLT which is called 'technology-mediated TBLT' talks about how "task-based language teaching can be fitted integrally into the new language education and digital technology realities" (González-Lloret \& Ortega, 2014, p. 1). Many distinguished researchers such as Doughty and Long (2003, 2009), Skehan (2003) and González-Lloret (2003, 2014) have acknowledged TBLT as a suitable framework that could be incorporated into technology to shape instructional designs for learners. Shrooten (2006) mentioned that there are innumerable advantages of integrating technology into language education including accommodating different learner-needs and abilities, motivating and involving learners greatly. González-Lloret (2007) developed modules based on second language acquisition principles and incorporating methodological principles suggested by Doughty and Long (2003). These modules contain task-based, computer-assisted materials for high-intermediate to advanced language learners.

Al-Balushi (2010) and Thomas and Reinders (2010) delved into the correlation between tasks and technology-facilitated communication. Al-Balushi (2010) explored task-based, synchronous, computer-mediated communication among EFL learners. He examines how students interact through technology and negotiate for meaning; the correlation between interaction time and task type; and students' insights into technology-facilitated TBLT. Similarly, the collection of articles in the book edited by Thomas and Reinders (2010) deal with 'synergies' between TBLT and Computer Assisted Language Learning (CALL), and recommend ways to design and carry out tasks with various technologies to promote language learning.

Technology, according to Reinders and White (2010), helps us in creating and delivering language learning materials in an effective way. Lai and Li (2011) examine how TBLT could be employed in technology-facilitated environments and also delineate several critical issues for further research in the area. Thomas (2013) discusses pedagogical implications associated with CALL and TBLT, and highlights the importance of CALL and TBLT researchers working together to improve planning, classifying and understanding tasks. González-Lloret (2015) provides hands-on information about the successful integration of technology into TBLT and the development of technology-mediated materials. Ziegler (2016) too is of the view that technology-mediated TBLT enhances second language performance. He also outlines that technology plays a great role in helping us realize the positive impact of TBLT features such as task design and task implementation on the success of second language acquisition.

González-Lloret and Ortega (2014) have pointed out that technology could be integrated by using any available task-based model. However, complete integration entails three conditions:

1) First, one should define what 'task' is to distinguish between a traditional classroom 
exercise and a virtual learning activity. The tasks in computer-mediated environment should focus on meaning rather than on form. They should be student-centered, reflect students' needs and wants and their digital skills. They should allow for higher-order learning by presenting a variety of opportunities to make students use real-life language and reflect on their learning process.

2) Second condition is that we should be aware of the fact that "technology is never neutral", and integrating technology into our syllabus brings along a variety of realworld tasks which "should become targets tasks and part of the curriculum".

3) Third, technology should be fully integrated into a TBLT curriculum at all levels, right from needs analysis to assessment and evaluation.

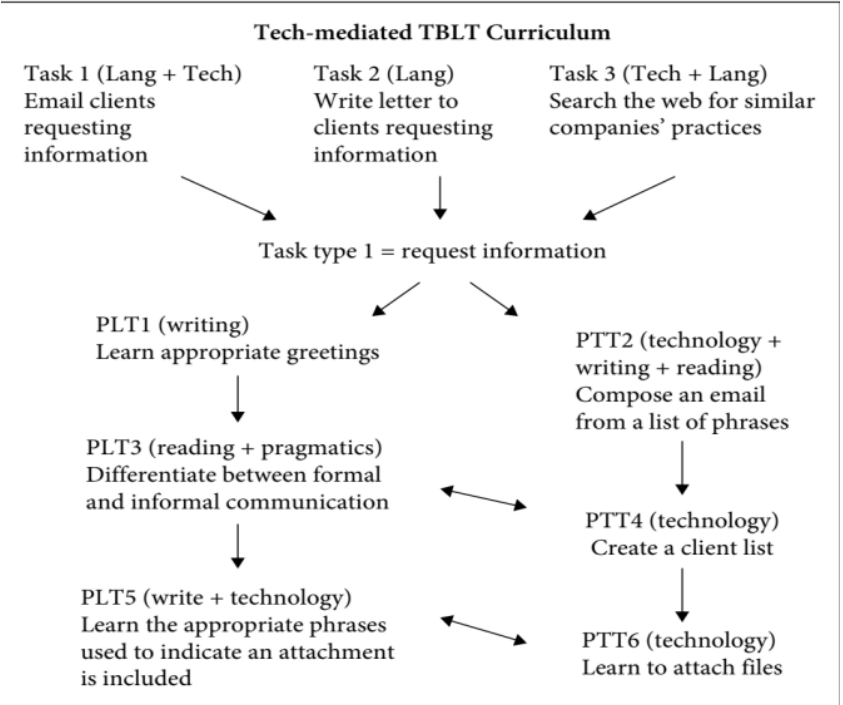

Figure 1. Tech-mediated TBLT curriculum (Marta González-Lloret, 2014, p. 44)

Task-based language teaching is one among many other methods to facilitate writing and speaking skills in an engaging way. A number of researchers (Colpin \& Van Gorp, 2007; Prabhu, 1987; Sachs, 2007) have employed collaborative writing techniques using TBLT to improve the writing skills of students. Research (Prabhu, 1987; Barkley, Cross \& Major, 2014) has shown that collaborative learning promotes student-centered learning, active interaction among learners and engages them in such a way that students take the lead for deeper learning. In addition, the successful performance of a task gives students a sense of achievement. Collaborative technology-mediated tasks also foster better communication among learners and students get motivated to enhance their language skills (González-Lloret, 2020).

The roles of students and teachers in TBLT change as the latter become facilitators and focus on students' needs. Teachers, according to Willis and Willis (2007), coordinate discussions, supervise pair/group work, and provide feedback on task performance. The important thing here is for the teacher to know to what extent they are responsible for facilitating language learning. Similarly, students play the role of active participants and become leaders in their own learning. Students, Van den Branden (2006) adds, negotiate course content or choose linguistic forms to perform tasks, thus becoming autonomous learners. 
Arab World English Journal (AWEJ) Special Issue on Covid 19 Challenges April 2021

Engaging Students Online with Technology-Mediated Task-Based

Vellanki \& Bandu

Richards and Rodgers (2004) say that teachers and learners are equally responsible for promoting classroom interaction in TBLT.

\section{Available Technologies and Task-Based Language Teaching}

Like other curricula, the TBLT curriculum is also based on analyzing the needs, wants and goals of learners. Additionally, technology-mediated TBLT requires the needs analysis (NA) of technological tools required to complete tasks, available technologies, learners' technical skills, resources and support. This NA is essential, according to González-Lloret (2015), to identify tasks that are appropriate for the learners, language points associated with these tasks, and the language that learners already know. Many researchers and educators have successfully tried to integrate TBLT with various technologies such as emails, chats, forums, blogs, wikis, Google docs, social media, online games, etc. as they meet the principles of TBLT, which are: learning by interaction, focusing on meaning, using authentic language and having a clearly defined goal. In fact, these technologies have increased opportunities for collaboration among learners and changed the way teachers and learners look at second language writing (Lee, 2010; Miyazoe \& Anderson, 2010). In a case study, Gasparini (2018), used WhatsApp for technologymediated tasks and discovered that the experience increased student motivation and interest to learn the Italian language. Reinhardt (2020) suggested a set of new metaphors (such as Windows, Mirrors, Doorways and Playgrounds) to describe the capacity of each to provide different authentic learning opportunities. He also indicated that social media could be integrated effectively to promote second language teaching and learning as the collaborative and participatory nature of most web2.0 technologies give teachers and learners several contexts for interaction. Wikis are adopted in collaborative writing by a number of researchers and educators (Lamb, 2004; Richardson, 2010). TBLT was implemented online using Google Classroom by Tusino, Faridi, Saleh \& Fitriati (2020) and their findings revealed that students perceived it positively and the method helped in improving students' writing skills. Learning Management Systems such as Moodle, Blackboard, Google Classroom, Edmodo, etc. could be used to assign a range of tasks to students in online environments. Platforms such as MS Teams, Zoom or Google Meet can provide students with the required opportunities to interact with their peers and teachers.

As the focus of the authors of this paper is on integrating technology using a TBLT model to create language/technology tasks based on the already established needs and syllabuses, we have worked on what technologies could be incorporated into these tasks to improve students' language skills and whether they possess the required digital skills to complete the tasks. To illustrate the point, if a target-task identified is opinion/discussion essay, we need to include the language required (giving personal opinion, disagreeing with someone, responding to an opinion, clarifying one's opinion, etc.) by the students to complete the tasks successfully. Along with these, what we also need are technology tasks that enable students to perform language tasks on e-platforms effectively, such as organizing information on Google docs, doing a language task using H5P, Padlet or Kahoot, or making a PowerPoint presentation using Zoom on a laptop or a smartphone. In this manner, technology dependent pedagogic tasks not only allow students to develop their language skills but also play a role in developing digital literacy. Since not many studies have been conducted on the application of using TBLT in online EFL contexts, we have come up with a few ideas to implement TBLT on the speaking 
Arab World English Journal (AWEJ) Special Issue on Covid 19 Challenges April 2021

Engaging Students Online with Technology-Mediated Task-Based

Vellanki \& Bandu

and writing performance of students. But before we do that, let us first look at how coursebook materials can help teachers in planning for TBLT lessons.

\section{Adapting Coursebooks for Task-Based Language Teaching}

Academicians working in various educational institutions and using coursebooks produced by different publishers understand that not many textbooks organize their material following a TBLT approach. In such a case, teachers do not have to prepare TBLT materials afresh, but can fine-tune the existing activities - such as changing the order of activities, avoiding some activities, or adding relevant goals - to suit their context. These strategies would certainly help teachers prepare TBL lessons with minimum effort (Hobbs, as cited in Willis, 2011). The first thing to do is to identify given tasks in textbooks and find out 'how task-like is it?' Willis provides six questions to teachers to determine if an activity has all the qualities of a task. He says, "The more confidently we say 'yes' to each of the questions, the more task-like the activity" (p. 13).

a) Does the activity engage learners' interest?

b) Is there a primary focus on meaning?

c) Is there an outcome?

d) Is success judged in terms of outcome?

e) Is completion a priority?

f) Does the activity relate to real-world activities?

Ellis (2009) extends the discussion by proposing the following criteria for a language activity to be considered a task:

a) The primary focus of a task should be on meaning.

b) A task should have a 'gap' (the learner needs to do something so as to complete the task).

c) A task requires the learners to use their own linguistic and non-linguistic resources.

d) A task should have a clearly defined outcome other than the use of language, i.e. the language should be just a medium to achieve the outcome.

In other words, the questions and statements given above by Willis (2011) and Ellis (2009) respectively lay down certain rules to design activities that promote real language use. After having looked at some fundamentals of technology-mediated TBLT, we will now see how to adapt different stages of the TBLT framework provided by Willis $(2011)$ and Ellis $(2003,2009)$ in a virtual classroom.

We find all kinds of tasks mentioned by TBLT advocates in coursebooks. However, the difference in the application of these tasks in TBLT lies in their treatment. For example, we find numerous exercises, matching activities, giving opinions, problem-solving, ranking discussions, presentations, interviews, etc. We will see how a 'task' can be differentiated from 'a grammar exercise' on the basis of criteria given by Ellis (2009). Ellis says that a grammar exercise may satisfy criteria ' $b$ ' and ' $c$ ' mentioned above, but does not meet ' $a$ ' and ' $d$ '. While learners spontaneously use a variety of language structures in a task to achieve the outcomes, they learn a specific grammar structure in advance to do a grammar exercise. As virtual learning was new to most learners in our context, we initially created input-based tasks to provide some language input to make learners use English comfortably. Learners were then prompted to use the same 


\section{Arab World English Journal (AWEJ) Special Issue on Covid 19 Challenges April 2021}

input in production tasks later in the virtual classroom. The primary aspect of technologymediated TBLT is to chalk out the basic format of the lesson. Therefore, for our classroom tasks, we decided to adopt the model proposed by Willis $(1996,2007)$.

\section{TBLT Sample Lessons Using Online Collaboration}

Based on the essential principles of TBLT and Willis's model of TBLT, some tasks have been prepared by the authors using available coursebook materials that are integrated with technology in order to improve the productive skills (speaking and writing) of Arab students in a virtual teaching context. The tasks are not designed with any particular linguistic focus but the aim is to facilitate EFL learners' comprehension of the textbook topics and to enable them to speak on those topics.

Lesson Plan One - adapted from Pathways 3 - Listening and Speaking (Chase \& Johannsen, 2012)

Learner level: Advanced

This task requires learners to listen to a text presented by the teacher to get the main ideas on the topic 'Human Migration'. Students work in pairs/small groups to practice the given questions on migration and take turns to report their answers to the rest of the class after the pair/group work.

Aims (Task outcome)

- What are the reasons for people's migration and what problems people face when they go to a new country?

- Finally, decide what are the two most common reasons for people's migration and two common problems encountered by people when they migrate to other countries. Extra questions:

- How does assimilation into a new culture mitigate their problems?

- What makes people happy in other countries?

This task-based lesson consists of three stages: pre-task, task-cycle and language focus. Along with the stages, the technologies that could be used are also mentioned. Please note that this list is not exhaustive. Since there are numerous technologies, the issue is not which technology to choose, but how skillfully we put the technological tool we know into use at various stages.

\section{Table 4. Lesson Plan 1}

\begin{tabular}{|c|c|c|}
\hline \multicolumn{3}{|l|}{ Pre-task } \\
\hline Introduction to topic and task & $\begin{array}{l}\text { Student } \\
\text { activity }\end{array}$ & $\begin{array}{l}\text { Technologies that } \\
\text { can be used }\end{array}$ \\
\hline $\begin{array}{l}\text { Setting the context - five minutes } \\
\text { Teacher introduces the topic of migration by showing } \\
\text { pictures of different nationalities working together, } \\
\text { pictures of people moving to different countries, etc. } \\
\text { The teacher arouses students' interest and activates } \\
\text { their schemata by asking the following questions: } \\
\text { What do you notice about the people in these pictures? } \\
\text { What is something unique about those people? }\end{array}$ & $\begin{array}{l}\text { Students } \\
\text { respond to } \\
\text { the pictures. } \\
\text { Students give } \\
\text { their } \\
\text { responses } \\
\text { based on }\end{array}$ & $\begin{array}{l}\text { Web conferencing } \\
\text { platform - MS } \\
\text { Teams/Zoom/Google } \\
\text { Meet } \\
\text { Show pictures in the } \\
\text { book or on } \\
\text { PowerPoint. }\end{array}$ \\
\hline
\end{tabular}




\begin{tabular}{|c|c|c|c|c|}
\hline \multicolumn{3}{|c|}{$\begin{array}{l}\text { Why do you think people go to other countries? } \\
\text { What are some problems that people face when they } \\
\text { immigrate to other countries? } \\
\text { Vocabulary activity - } 10 \text { minutes } \\
\text { The teacher elicits useful words and phrases, gives the } \\
\text { class some more exposure to language related to human } \\
\text { migration by carrying out a vocabulary activity on p. } \\
44 \text {. } \\
\text { Focus: preparing students for the main task by drawing } \\
\text { their attention to learning new vocabulary, phrases, and } \\
\text { the context. } \\
\text { The teacher sets the task and gives task instructions by } \\
\text { asking them to find out } \\
\text { the reasons why people migrate to other countries. } \\
\text { The problems that people face when they go to other } \\
\text { countries. } \\
\text { Listening activity - } 10 \text { minutes } \\
\text { The teacher will introduce a listening task (noticing } \\
\text { task) to students to explicitly provide them language } \\
\text { clues that will help them in the main task, which is } \\
\text { finding out the reasons for migration or the experiences } \\
\text { of people in the context of human migration. The } \\
\text { students will listen to a recorded conversation and } \\
\text { understand a few reasons why people migrate to other } \\
\text { countries. They will then compare their answers with } \\
\text { the reasons they gave during the brainstorming session. }\end{array}$} & $\begin{array}{l}\text { Students } \\
\text { notice some } \\
\text { relevant } \\
\text { words / } \\
\text { phrases about } \\
\text { the topic. } \\
\text { Students } \\
\text { notice the } \\
\text { vocabulary in } \\
\text { context and } \\
\text { use them in } \\
\text { their and } \\
\text { others' } \\
\text { answers. }\end{array}$ & $\begin{array}{l}\text { Get feedback } \\
\text { through the chatbox } \\
\text { or interactive } \\
\text { whiteboard } \\
\text { (or word clouds such } \\
\text { as } \\
\text { Padlet/Answer } \\
\text { Garden) }\end{array}$ \\
\hline \multicolumn{5}{|c|}{$\begin{array}{l}\text { In the task phase, the actual task will be performed by the students in } \\
\text { groups of three or four. }\end{array}$} \\
\hline $\begin{array}{r}\text { Task }(\mathrm{br} \\
\text { roon }\end{array}$ & $\begin{array}{l}\text { Planning } \\
\text { (breakout } \\
\text { rooms) }\end{array}$ & & & \\
\hline $\begin{array}{l}\text { Students plan to } \\
\text { describe the } \\
\text { reasons for } \\
\text { human migration } \\
\text { and the problems } \\
\text { people face in } \\
\text { new countries. } \\
\text { They brainstorm } \\
\text { ideas and discuss } \\
\text { with their peers. }\end{array}$ & $\begin{array}{l}\text { Students plan } \\
\text { the outline of } \\
\text { their report } \\
\text { based on the } \\
\text { points they } \\
\text { gathered in } \\
\text { the previous } \\
\text { phase. } \\
\text { The teacher } \\
\text { monitors and } \\
\text { provides } \\
\text { necessary } \\
\text { help in the }\end{array}$ & $\begin{array}{l}\text { Students come } \\
\text { back from } \\
\text { breakout rooms. } \\
\text { They take turns to } \\
\text { present their } \\
\text { report to the } \\
\text { whole group. } \\
\text { Teacher guides } \\
\text { turn-taking, } \\
\text { notices the } \\
\text { language to give } \\
\text { corrective }\end{array}$ & $\begin{array}{l}\text { Students } \\
\text { notice the } \\
\text { vocabulary in } \\
\text { context used } \\
\text { by others and } \\
\text { use them in } \\
\text { their } \\
\text { answers. }\end{array}$ & $\begin{array}{l}\text { Corrective feedback } \\
\text { can be typed } \\
\text { simultaneously in } \\
\text { the chatbox itself as } \\
\text { students report or } \\
\text { type in a word file to } \\
\text { share it later. }\end{array}$ \\
\hline
\end{tabular}


Arab World English Journal (AWEJ) Special Issue on Covid 19 Challenges April 2021

Engaging Students Online with Technology-Mediated Task-Based

Vellanki \& Bandu

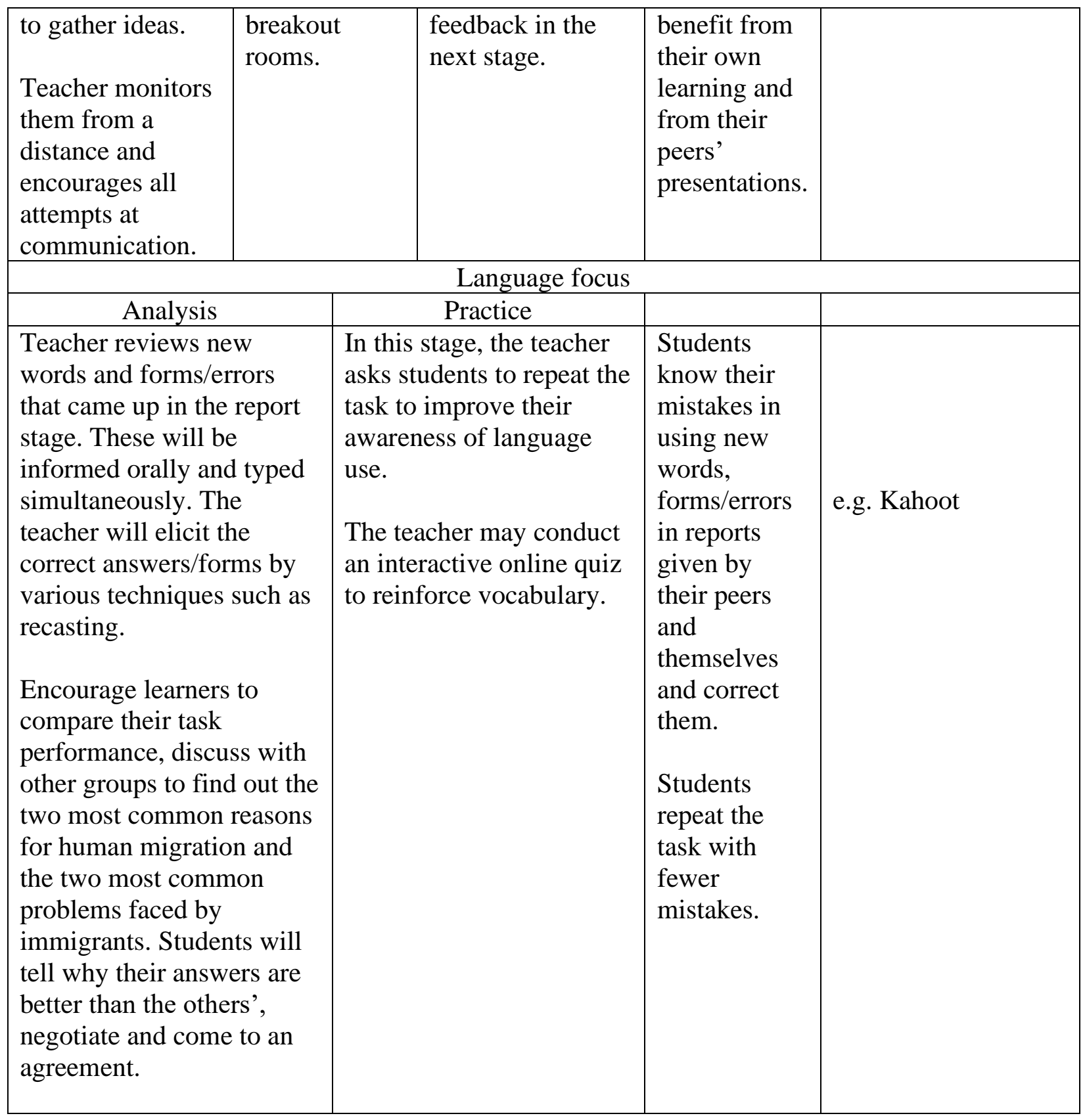

Lesson Plan Two - adapted from Q Skills 2 - Listening and Speaking (Brooks, 2010) Learner level: Pre-intermediate

Aims (Task outcome)

- Listen to a news report and a video, gather information and ideas to give a presentation about the Do-It-Yourself (DIY) technique you have learnt. Extra questions:

- Which, among the reported ones, is the most effective, easiest and most useful DIY technique? 
Arab World English Journal (AWEJ) Special Issue on Covid 19 Challenges April 2021

Engaging Students Online with Technology-Mediated Task-Based

Vellanki \& Bandu

Table 5. Lesson Plan 2

\begin{tabular}{|c|c|c|c|c|}
\hline \multicolumn{5}{|c|}{ Pre-task } \\
\hline \multicolumn{3}{|c|}{ Introduction to topic and task } & $\begin{array}{l}\text { Student } \\
\text { activity }\end{array}$ & $\begin{array}{l}\text { Technologies that } \\
\text { can be used }\end{array}$ \\
\hline \multicolumn{3}{|c|}{$\begin{array}{l}\text { Setting the context } \\
\text { The instructor introduces the task by giving them a list } \\
\text { of things and asking them whether they do those things } \\
\text { themselves or depend on others. The instructor can } \\
\text { extend the conversation by asking them further } \\
\text { questions, such as where they learnt those things, who } \\
\text { taught them, etc., and ask them to jot down what other } \\
\text { things they could do. } \\
\text { Vocabulary activity } \\
\text { The teacher will introduce the vocabulary (related to } \\
\text { asking for clarification and giving clarification) through } \\
\text { a listening activity. } \\
\text { Watching a video } \\
\text { The instructor will play a video (noticing task) to } \\
\text { explicitly provide students language clues that will help } \\
\text { them in the main task, which is finding out a DIY } \\
\text { technique from YouTube. The instructor will ask } \\
\text { students whether they have ever done something like } \\
\text { that on their own. This will get them thinking about } \\
\text { activities that they could do themselves; it will spark } \\
\text { their interest and motivate them as it is a real-life task. }\end{array}$} & $\begin{array}{l}\text { Students } \\
\text { listen and } \\
\text { watch the } \\
\text { video. } \\
\text { Students } \\
\text { respond to } \\
\text { the } \\
\text { questions. }\end{array}$ & $\begin{array}{l}\text { Web } \\
\text { conferencing } \\
\text { platform - MS } \\
\text { Teams/Zoom/ } \\
\text { Google Meet } \\
\text { To get feedback } \\
\text { through word } \\
\text { clouds - } \\
\text { Padlet/Answer } \\
\text { Garden } \\
\text { Google docs }\end{array}$ \\
\hline \multicolumn{5}{|c|}{ Task cycle } \\
\hline \multicolumn{5}{|c|}{$\begin{array}{l}\text { In the task phase, the actual task will be performed by } \\
\text { the students in groups. }\end{array}$} \\
\hline Task & Planning & Report & & \\
\hline $\begin{array}{l}\text { Students will } \\
\text { be in groups of } \\
\text { three or four } \\
\text { for this lesson. } \\
\text { The teacher } \\
\text { will ask them } \\
\text { to come up } \\
\text { with something } \\
\text { that they could } \\
\text { do in a group. } \\
\text { Other students } \\
\text { may not be } \\
\text { aware of } \\
\text { certain things } \\
\text { and they learn } \\
\text { it from one } \\
\text { another. }\end{array}$ & $\begin{array}{l}\text { During the } \\
\text { preparation, one } \\
\text { student from each } \\
\text { group will note } \\
\text { down the } \\
\text { technique } \\
\text { discussed and later } \\
\text { organize the } \\
\text { points. They will } \\
\text { use all their } \\
\text { linguistic and non- } \\
\text { linguistic } \\
\text { resources to } \\
\text { understand the } \\
\text { processes of DIY } \\
\text { techniques to } \\
\text { explain later. They }\end{array}$ & $\begin{array}{l}\text { In the reporting } \\
\text { phase, one } \\
\text { student from } \\
\text { each group } \\
\text { presents their } \\
\text { DIY technique } \\
\text { to the whole } \\
\text { class. While one } \\
\text { student speaks, } \\
\text { another student } \\
\text { from the same } \\
\text { group could } \\
\text { show what they } \\
\text { have written to } \\
\text { the whole class. } \\
\text { They could } \\
\text { either upload }\end{array}$ & $\begin{array}{l}\text { Students } \\
\text { learn new } \\
\text { words, } \\
\text { phrases, and } \\
\text { forms from } \\
\text { others. }\end{array}$ & \\
\hline
\end{tabular}


Arab World English Journal (AWEJ) Special Issue on Covid 19 Challenges April 2021

Engaging Students Online with Technology-Mediated Task-Based

Vellanki \& Bandu

\begin{tabular}{|c|c|c|c|c|c|}
\hline $\begin{array}{l}\text { Students need } \\
\text { to prepare for a } \\
\text { DIY technique } \\
\text { and then report } \\
\text { to the whole } \\
\text { class. }\end{array}$ & $\begin{array}{l}\text { will als } \\
\text { resourc } \\
\text { internet } \\
\text { underst } \\
\text { vocabu } \\
\text { to expla } \\
\text { class w } \\
\text { whose } \\
\text { is the e } \\
\text { most us } \\
\text { have ar } \\
25 \text { min } \\
\text { think al } \\
\text { techniq } \\
\text { brainstc } \\
\text { discuss } \\
\text { friends, } \\
\text { prepare }\end{array}$ & $\begin{array}{l}\text { use other } \\
\text { like the } \\
\text { o } \\
\text { nd the } \\
\text { ry needed } \\
\text { n. The } \\
\text { l decide } \\
\text { chnique } \\
\text { iest and } \\
\text { ful. They } \\
\text { und } 20- \\
\text { es to } \\
\text { ut a DIY } \\
\text {, } \\
\text { m ideas, } \\
\text { vith } \\
\text { and } \\
\text { report. }\end{array}$ & $\begin{array}{l}\text { their } \\
\text { image/technique } \\
\text { or type the } \\
\text { whole process in } \\
\text { the chat box or } \\
\text { on the } \\
\text { interactive } \\
\text { board. The } \\
\text { teacher will also } \\
\text { be able to } \\
\text { engage the other } \\
\text { learners from } \\
\text { the group. }\end{array}$ & & \\
\hline \multicolumn{6}{|c|}{ Language focus } \\
\hline \multicolumn{2}{|l|}{ Analysis } & \multicolumn{2}{|r|}{ Practice } & & \\
\hline \multicolumn{2}{|c|}{$\begin{array}{l}\text { The teacher will also } \\
\text { come up with some } \\
\text { language points and } \\
\text { vocabulary they used } \\
\text { and give them the } \\
\text { required feedback. } \\
\text { The instructor will let } \\
\text { the class discuss the } \\
\text { most effective, easiest } \\
\text { and most useful } \\
\text { techniques and come up } \\
\text { with one decision. }\end{array}$} & \multicolumn{2}{|c|}{$\begin{array}{l}\text { In the final phase (repeat } \\
\text { task/practice phase), } \\
\text { students will practice again } \\
\text { after getting inputs from the } \\
\text { teacher on language and } \\
\text { vocabulary. }\end{array}$} & $\begin{array}{l}\text { Students } \\
\text { learn from } \\
\text { their own } \\
\text { and others' } \\
\text { mistakes. } \\
\text { Students } \\
\text { decide on } \\
\text { the best DIY } \\
\text { technique. }\end{array}$ & \\
\hline
\end{tabular}

Lesson Plan Three - In-house materials (Writing Guide, 2018)

Level: Advanced - Level four - Foundation program

Students learn to:

- Watch a video and answer questions about the structure of a discussion essay; how various parts of the essay are written

- Collaboratively work on Google forms to produce a discussion essay

\section{The Use of Google Docs}

Google docs and Wikis could be used to make students collaborate and write essays. The features of these word processing tools are similar to Microsoft Word and benefit both students and teachers. We believe that these tools will help learners to improve their writing skills and achieve a better degree of coherence and cohesion in 
their writing. One advantage is that learners can use these tools irrespective of their level of language proficiency. In addition, students can collaborate with one another and with the teacher real-time to develop and edit a collaborative writing text. In the following task, Google docs is selected to design all sequences of the task to be implemented in synchronous and asynchronous modes. This activity will also follow the sequence of pre-task, task cycle and language focus.

Table 6. Lesson Plan 3

\begin{tabular}{|c|c|c|c|c|}
\hline \multicolumn{5}{|c|}{ Pre-task } \\
\hline \multicolumn{3}{|l|}{ Introduction to topic and task } & $\begin{array}{l}\text { Student } \\
\text { activity }\end{array}$ & $\begin{array}{l}\text { Technologies } \\
\text { that can be used }\end{array}$ \\
\hline \multicolumn{3}{|c|}{$\begin{array}{l}\text { Setting the context } \\
\text { During the pre-task phase, the instructor presents the topic } \\
\text { and task to the students with the help of a few pictures and } \\
\text { activates their schemata and background knowledge on the } \\
\text { topic. The teacher will also encourage them to think about } \\
\text { ideas related to the topic and write them freely. } \\
\text { The teacher uses various techniques to elicit the ideas from } \\
\text { learners (by giving prompts, by focusing on particular things } \\
\text { in pictures, etc.) } \\
\text { Clarifying the goal } \\
\text { The teacher sets the task by adding a goal and telling } \\
\text { students that they are supposed to write a collaborative } \\
\text { discussion essay on whether a two-semester system is better } \\
\text { or a trimester. } \\
\text { The teacher presents a task model, highlights some language } \\
\text { structures and draws students' attention to certain } \\
\text { expressions and phrases related to the chosen essay and } \\
\text { elicits some other phrases/expressions/vocabulary that they } \\
\text { could use during their writing. }\end{array}$} & $\begin{array}{l}\text { Students } \\
\text { learn new } \\
\text { words, } \\
\text { expressions, } \\
\text { and forms to } \\
\text { be used later } \\
\text { in their } \\
\text { writing. }\end{array}$ & $\begin{array}{l}\text { Web } \\
\text { conferencing } \\
\text { platform - MS } \\
\text { Teams/Zoom/ } \\
\text { Google Meet } \\
\text { breakout rooms } \\
\text { To get feedback } \\
\text { through word } \\
\text { clouds - } \\
\text { Padlet/Answer } \\
\text { Garden }\end{array}$ \\
\hline \multicolumn{5}{|c|}{ Task cycle } \\
\hline \multicolumn{5}{|c|}{$\begin{array}{l}\text { In the task phase, the actual task will be performed by the } \\
\text { students in groups. }\end{array}$} \\
\hline Task & Planning & Report & & \\
\hline $\begin{array}{l}\text { In this stage, the teacher } \\
\text { asks the learners to } \\
\text { organize their ideas on } \\
\text { Google docs and write } \\
\text { about the given topic. The } \\
\text { learners will work in pairs } \\
\text { or in groups based on the } \\
\text { difficulty of the task and } \\
\text { get the required assistance } \\
\text { from their peers. The } \\
\text { teacher also monitors and } \\
\text { helps students to write }\end{array}$ & $\begin{array}{l}\text { During the } \\
\text { planning stage, the } \\
\text { participants } \\
\text { rewrite and draft } \\
\text { their writing using } \\
\text { the structure of a } \\
\text { discussion/ } \\
\text { opinion essay. The } \\
\text { teacher lets the } \\
\text { students take } \\
\text { advantage of peer } \\
\text { inputs/feedback }\end{array}$ & $\begin{array}{l}\text { The } \\
\text { instructor } \\
\text { asks the } \\
\text { groups to } \\
\text { present } \\
\text { the essay } \\
\text { on screen } \\
\text { and } \\
\text { explain } \\
\text { their } \\
\text { points to } \\
\text { the whole }\end{array}$ & $\begin{array}{l}\text { Students } \\
\text { prepare and } \\
\text { present their } \\
\text { writing. }\end{array}$ & \\
\hline
\end{tabular}


Arab World English Journal (AWEJ) Special Issue on Covid 19 Challenges April 2021

Engaging Students Online with Technology-Mediated Task-Based

Vellanki \& Bandu

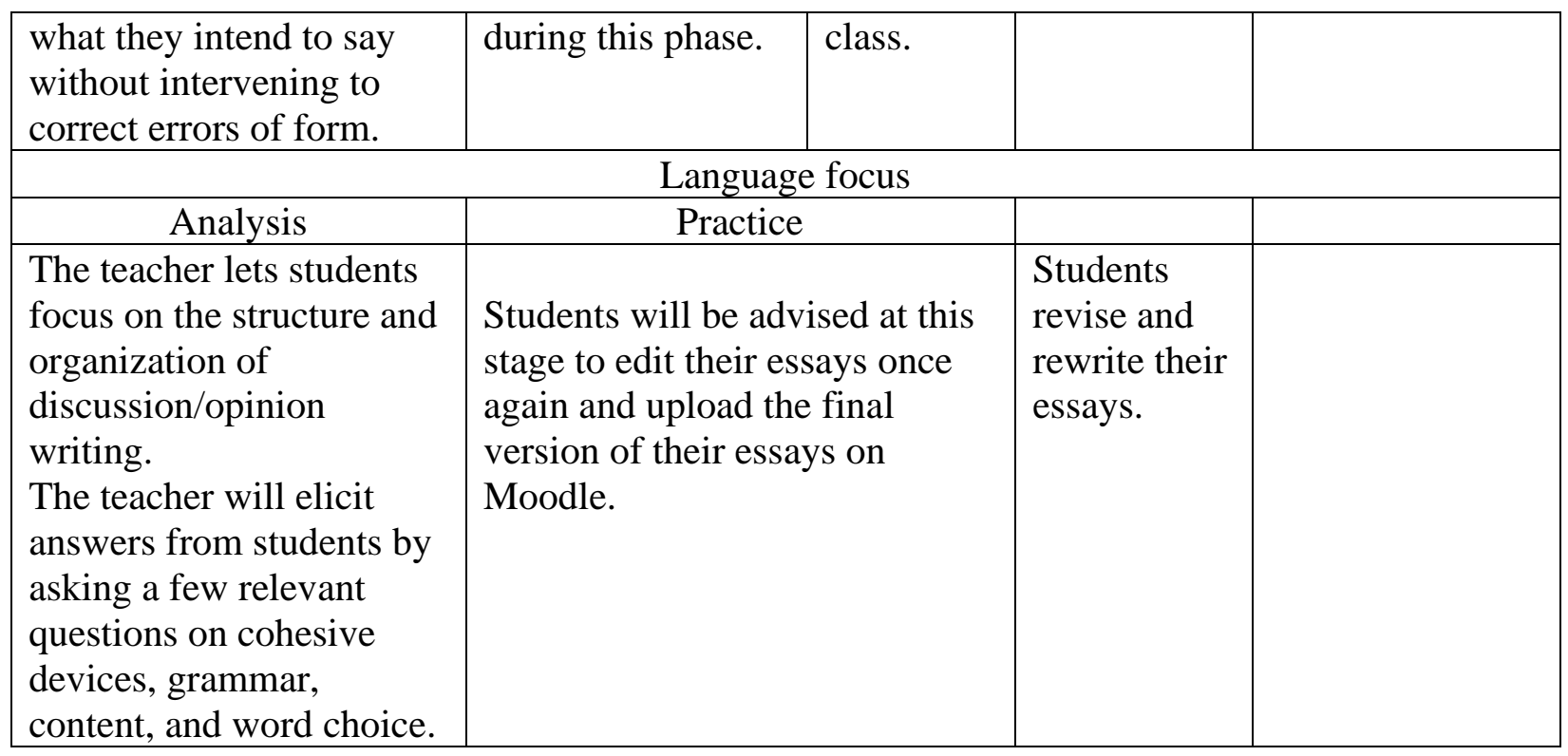

The authors believe that these task-based examples allow students to accomplish the tasks initially by using their existing resources. Students will not be forced to use the language provided by the teacher during the pre-task, but will be encouraged to think about the required language features to improve the task performance in the repeat task. As the focus of TBLT tasks is on communication and fluency, the teacher can achieve a balance between both by facilitating proper guidance at suitable stages of the task. The tasks given above exemplify how tasks could be altered/edited from coursebooks to suit other topics/contexts.

\section{Assessment of Tasks Based on Performance}

Student assessment is a very important component of evaluation. It is understandable that normal classroom task assessment rubric is not enough to assess students, and it has to be modified to include a few other components. Formative assessment, according to Norris (2009), serves as a motivational factor for students (as cited in González-Lloret, 2014). It also offers a referential framework for teachers and students to understand the efficacy of virtual classroom activities. Teachers can also provide individual feedback to learners to motivate them to do better.

In our learning context, we provided a self-evaluation checklist of things for students to mark based on their understanding of the task and the process of learning. It has items related to task achievement, task relevance, task performance, task participation, language focus and task outcome. Such self-assessment enables students to reflect on their own learning and promotes autonomous learning too (Ellis, 2003). Besides, it also stimulates them to set goals for themselves and makes them conscious of what they should do and how they should prepare for next tasks. In EFL/ESL contexts, peer assessment is one aspect that teachers should not ignore as learners tend to have a very correct opinion of their peers' performances. Apart from that, the teacher too can award a particular score to participants based on students' language use and task characteristics mentioned above. 
Arab World English Journal (AWEJ) Special Issue on Covid 19 Challenges April 2021

\section{Anticipated Challenges and Solutions}

On account of the fact that both students and institutions/educators have been suddenly thrust into the unfamiliar virtual environment and forced to adapt to the new conditions hurriedly, there is a possibility that they may not be able to meet the expectations in using technology-mediated TBLT.

- One of the challenges could be that teachers should be well aware of appropriate technological tools for different tasks and their use.

A possible solution: The solution is always to be proactive and apply self-learning methods to keep oneself abreast of the latest tools and technologies.

- Lack of teacher creativity and adaptability (Carless, 2007) could be a problem as it can negatively impact students' motivation levels and their language skills.

A possible solution: Teachers should be as creative and adaptable as possible to create a variety of authentic tasks related to students' real-life experiences.

- Another challenge could be student participation. Students might come up with network and connectivity issues when they feel that they cannot perform the task. In other words, task complexity and choice of tasks are two challenges because of which some learners show reluctance to speak and participate in tasks.

A possible solution: Teachers should make sure that the goal and final outcome are clear to students. Often, task complexity and irrelevant tasks can become reasons for students' lack of interest in participation. Teachers should take care to sequence tasks in increasing order of difficulty. They could also change the interaction patterns, from individual to pairs, to groups, whole class, etc.

- Lee (2001) identified problems with group dynamics, negotiated meaning, interaction and 'focus on form' components in technology enhanced learning.

A possible solution: Teachers should make learners reflect on the tasks and make them repeat with other partners. Teachers should make sure that students collaborate beyond the virtual classroom by giving them collaborative task-based projects that will be later presented in class. Teachers should also give feedback on learners' work regularly and encourage them to perform better.

- The duration of lectures is a commonly faced problem by many teachers.

A possible solution: In the current forced online teaching situation, having student attention for longer periods of time is next to impossible. Therefore, teachers should consider breaking lectures up into two or three mini-lectures (including recorded ones), having online interactive quizzes (such as Kahoot, Nearpod, etc.) after each short lecture. Institutions should also deal with this issue at the policy level.

Overall, universities/colleges must conduct professional development programs for teachers to prepare them for the challenges. Teachers should also keep themselves abreast of the latest technological developments in TBLT.

\section{Conclusion}

The authors are of the view that to have better interaction and engagement among students in virtual classes, teachers should use textbooks that offer some flexibility, modify materials to make the activities into suitable tasks and notice how learners use language with the available linguistic and non-linguistic resources. It is imperative to repeat tasks to observe improvement and evaluate what can be done better next time. If educators put these ideas into practice, it is highly possible that technology-mediated task-based collaborative approach will 
Arab World English Journal (AWEJ) Special Issue on Covid 19 Challenges April 2021

Engaging Students Online with Technology-Mediated Task-Based

Vellanki \& Bandu

prove to be a viable pedagogical framework in improving the language skills of students and also establish the merits of a technology-mediated language learning environment.

\begin{abstract}
About the Authors:
Dr. Surya Subrahmanyam Vellanki is currently working at University of Technology and Applied Sciences, Nizwa, Oman. He received his Ph.D. in English in 2004 and Cambridge DELTA in 2016. His research interests are language assessment, language learning in technology enhanced, virtual and digital environments, learning strategies and TBLT. ORCID: https://orcid.org/0000-0002-0877-652X
\end{abstract}

Sasidhar Bandu is an EFL Lecturer at Prince Sattam Bin Abdulaziz University, Saudi Arabia. His areas of research interest are teaching English with technology, learner autonomy, teacher education and CPD. ORCID: https://orcid.org/0000-0002-1899-9479

\title{
References
}

Al-Bulushi, A. (2010). Task-based computer-mediated negotiation in an EFL context: The ins and outs of online negotiation of meaning using language learning tasks. Saarbrücken, Germany: VDM Verlag Dr. Müller.

Barkley, E. F., Howell Major, C., \& Cross, K. (2014). Collaborative Learning Techniques: A Handbook for College Faculty ( $2^{\text {nd }}$ ed.). San Francisco: Jossey-Bass.

Breen, M. (1987). Learner contributions to task design. In C. Candlin, \& D. Murphy, (Eds.), Language Learning Tasks (pp. 23-46). Englewood Cliffs NJ: Prentice-Hall.

Breen, M. (1989). The evaluation cycle for language learning tasks. In R. K. Johnson, (Ed.). The second language curriculum. Cambridge: Cambridge University Press.

Brooks, M. (2010). Q: Skills for Success - Listening and Speaking 2. Oxford: Oxford University. Press.

Carless, D. (2007). The suitability of task-based approaches for secondary schools: Perspectives from Hong Kong. System, 35(4), 595-608

Chase, B.T., Johannsen, K.L. (2012). Pathways 3: Listening, speaking and critical thinking. Independence, KY: Heinle Cengage.

Colpin, M., \& Gorp, K.V. (2007). Task-based writing in primary education: The development and evaluation of writing skills through writing tasks, learner and teacher support. In K. Van den Branden, K. Van Gorp, \& M. Verhelst, M. (Eds.), Tasks in action: Education from a classroom-based perspective (pp. 194-234). Cambridge, UK: Cambridge University Press.

Doughty, C., \& Long, M. H., (2003). The handbook of second language acquisition. Oxford, England: Blackwell.

Ellis, R. (2003). Task-based language learning and teaching. Oxford: Oxford University Press.

Ellis, R. (2009). Task--based language teaching: Sorting out the misunderstandings.

International Journal of Applied Linguistics, 19(3), 221--246.

https://doi.org/10.1111/j.1473-4192.2009.00231.x

Gasparini, A. (2018). Building Tasks with Instant Messaging Apps. e-mentor, 5(77), 24-29. DOI: https://doi.org/10.15219/em77.1385 
Arab World English Journal (AWEJ) Special Issue on Covid 19 Challenges April 2021

González-Lloret, M. (2003). Designing task-based CALL to promote interaction: En busca de Esmeraldas. Language Learning \& Technology, 7(1), 86-104. Retrieved from http://llt.msu.edu/vol7num1/gonzalez/default.html

González-Lloret, M. (2007). Implementing task-based language teaching on the web. In K. Van den Branden, K. V. Gorp, M. Verhelst, (Eds.), Task-based language education (pp. 265-284). Cambridge, UK: Cambridge Scholars Press.

González-Lloret, M. (2014). The need for needs analysis in technology-mediated TBLT. In M. González-Lloret, \& L. Ortega (Eds.), Technology-mediated TBLT: Researching technology and tasks (pp. 23-50). Amsterdam, Philadelphia: John Benjamins Publishing Company.

González-Lloret, M., \& Ortega, L. (2014). Towards Technology-mediated TBLT: An introduction. In M. González- Lloret, \& L. Ortega (Eds.), Technology-mediated TBLT: researching technology and tasks (pp. 1-22). Amsterdam, Philadelphia: John Benjamins Publishing Company.

González-Lloret, M. (2015). A practical guide to integrating technology into task-based language teaching. Washington DC: Georgetown University Press.

González-Lloret, M. (2020). Collaborative tasks for online language teaching. Foreign Language Annals, 53, 260-269.

Lai, C., \& Li, G.F. (2011). Technology and task-based language teaching: A critical Review. CALICO Journal, 28, 498-521.

Lamb, B. (2004). Wide open spaces: Wikis, ready or not. Education Review, 39(5), 36-48.

Lee, J. F. (2000). Tasks and communicating in language classrooms. Boston, MA: McGraw-Hill.

Lee, L. (2001). Online interaction: negotiation of meaning and strategies used among learners of Spanish. ReCALL, 13 (2), 232-244.

Lee, L. (2010). Fostering reflective writing and interactive exchange through blogging in an advanced language course. ReCALL, 22 (2), 212-227. DOI: https://doi.org/10.1017/S095834401000008X

Long, M. H.. (1985). A role for instruction in Second Language Acquisition: Task-based language teaching. In K. Hyltenstam, \& M. Pienemann, (Eds.), Modeling and assessing second language development (pp. 77-99). Clevedon, Avon: Multilingual Matters.

Long, M. H., \& Doughty, C. J. (eds.). (2009). Handbook of language teaching. Oxford: Blackwell-

Long, M. (2015). Second language acquisition and task-based language teaching. Chichester, UK: John Wiley \& Sons

Miyazoe, T., \& Anderson, T. (2010). Learning outcomes and students' perceptions of online writing:

Simultaneous implementation of a forum, blog, and wiki in an EFL blended learning setting. System,38 (2), 185-199. https://doi.org/10.1016/j.system.2010.03.006

Norris, J. M. (2009). Task-based teaching and testing. In M. H. Long, \& C. J. Danielhty (Eds.), Handbook of language teaching (pp. 578-594). Oxford, UK: Blackwell.

Nunan, D. (2004). Task-Based Language Teaching. Cambridge: Cambridge University Press.

Prabhu, N. S. (1987). Second language pedagogy: a perspective. Oxford: Oxford University Press.

Reinders, H., \& White, C. (2010). The theory and practice of technology in materials development and 
Arab World English Journal (AWEJ) Special Issue on Covid 19 Challenges April 2021

task design. In N. Harwood (Ed.), Materials in ELT: Theory and practice (pp. 58-80).

Cambridge: Cambridge University Press.

Reinhardt, J. (2020). Metaphors for social media-enhanced foreign language teaching and learning. Foreign Language Annals, 53(2), 234-242. https://doi.org/10.1111/flan.12462

Richards, J., \& Rodgers, T. (2004). Approaches and methods in language teaching. Cambridge: Cambridge University Press.

Richards, J. C., \& Schmidt, R. W. (2010). Longman dictionary of language teaching and applied linguistics. (Longman dictionary of language teaching and applied linguistics.) Harlow: Longman.

Richardson, W. (2010). Blogs, wikis, podcasts, and other powerful web tools for classrooms $\left(3^{\text {rd }}\right.$ ed.).

Thousand Oaks, CA: Corwin.

Sachs, G.T. (2007). The challenges of adopting and adapting task-based cooperative teaching and learning in an EFL context. In K. Van den Branden, Van Gorp, \& M. Verhelst, M. (Eds.), Tasks in action: Education from a classroom-based perspective (pp. 235264). Cambridge, UK: Cambridge University Press.

Samuda, V., \& Bygate, M. (2008). Tasks in second language learning. Basingstoke: Palgrave MacMillan

Schrooten, W. (2006). Task-based language teaching and ICT: Developing and assessing interactive multimedia for task-based language teaching. In K, Van den Brande (Ed.), Task-Based Language Education: From Theory to Practice. (pp. 129-150). New York, NY: Cambridge University Press.

Skehan, P. (1996). A framework for the implementation of task-based instruction. Applied linguistics, 17(1), 38-62. https://doi.org/10.1093/applin/17.1.38

Skehan, P. (2003). Task-based instruction. Language Teaching, 36(1), 1-14. doi:10.1017/ S026144480200188X

Thomas, M. (2013). Task-based language teaching and CALL. In M. Tomas, H. Reinders, \& M. Warschauer (Eds.), Contemporary computer-assisted language learning (pp. 341-58). London,UK: Continuum.

Thomas, M., \& Reinders (Eds.). (2010). Task-based language learning and teaching with technology. London, UK: Continuum.

Tusino, T., Faridi, A., Saleh, M., \& Fitriati, S. (2020). Student Engagement in Hybrid TaskBased Language Teaching in EFL Writing Class. Proceedings of the 5th International Conference on Science, Education and Technology, ISET 2019, 29th June 2019, Semarang, Central Java, Indonesia http://dx.doi.org/10.4108/eai.29-6-2019.2290384

Van den Branden, K. (2006). Task-based language teaching: From theory to practice. Cambridge: Cambridge University Press

Van den Branden, K., Bygate, M., \& Norris, J. M. (Eds.). (2009). Task-based language teaching: A reader. Amsterdam, The Netherlands: John Benjamins.

Willis, J. (1996). A Framework for Task-based Learning. Oxford: Longman.

Willis, D., \& Willis, J. (2007). Doing Task-Based Teaching. Oxford: Oxford University Press. Willis, D., \& Willis, J. (2011). Task-based learning and learner motivation. On Task, 1(1), 7. Writing Guide, Level 4. (2018), Nizwa College of Technology, Oman.

Ziegler, N. (2016). Taking Technology to Task: Technology-Mediated TBLT, Performance, and Production. Annual Review of Applied Linguistics, 36, 136-163. https://doi.org/10.1017/S0267190516000039 